\title{
Swern Oxidation of Bicyclo[2.2.1]hept-5-ene-2,3-diol and Its Pyrazine-fused Derivatives: An Improved Synthesis of Bicyclo[2.2.1]hept-5-ene-2,3-dione and An Unexpected Ring- Opening Reaction
}

\author{
Tomoshige Kobayashi* and Sayuri Kobayashi \\ Department of Chemistry, Faculty of Science, Shinshu University, Matsumoto 390-8621, Japan \\ Tel.: (263) 37-2470, Fax: (263) 37-2470, E-mail: tkobaya@ gipac.shinshu-u.ac.jp
}

Received: 14 August 2000 / Accepted: 6 September 2000 / Published: 9 September 2000

\begin{abstract}
An improved synthesis of bicyclo[2.2.1]hept-5-ene-2,3-dione by Swern oxidation of bicyclo[2.2.1]hept-5-ene-2,3-diol, and an unexpected ring-opening reaction by the Swern oxidation of pyrazine-fused congeners are described.
\end{abstract}

Keywords: Swern oxidation, vicinal cis-diol, $\alpha$-diketone, ring-opening, norbornene, pyrazine.

\section{Introduction}

Bicyclo[2.2.1]heptane skeletons have been a useful building block for the construction of molecular architectures with a concavity [1]. In the course of our studies to synthesize a host molecule utilizing a negative electrostatic potential filed of pyrazine rings, a general method to prepare norobornene-2,3-dione and its pyrazine-fused derivatives was required. We describe here an improved synthesis of bicyclo[2.2.1]hept-5-ene2,3-dione (3) by Swern oxidation of bicyclo[2.2.1]hept-5-ene-2,3-diol (6). We also report that a similar Swern oxidation reaction of pyrazine-fused congeners $\mathbf{1 0}$ and $\mathbf{1 1}$ was found to undergo an unexpected rringopening reaction.

\section{Results and Discussion}

Previously, bicyclo[2.2.1]hept-5-ene-2,3-dione (3) was prepared by the Diels-Alder reaction of cyclopentadiene with dichlorovinylene carbonate (1) giving the adduct $\mathbf{2}$, followed by hydrolysis [2]. Dichlorovinylene carbonate (1) can be prepared by the reductive dechlorination reaction of tetrachloroethylene carbonate [3]. However, the synthesis of tetrachloroethylene carbonate is troublesome because the use of a large amount of chlorine gas is required [3]. Furthermore, we could not reproduce the reported yield of the Diels-Alder re- 
action of 1 with cyclopentadiene: the adduct 2 was obtained only in 40-50\% yields whereas $65-70 \%$ yields were claimed in the literature [3]. Thus, we report here an improved synthesis of $\mathbf{1}$ starting from more readily available vinylene carbonate (4) [4].

Bicyclo[2.2.1]hept-5-ene-2,3-diol (6) was prepared by the Diels-Alder reaction of vinylene carbonate (4) and cyclopentadiene followed by the hydrolysis as described in the literature [5]. The total yield for the two steps was 78\%. The Swern oxidation of $\mathbf{6}$ with dimethyl sulfoxide and oxalyl chloride provided $\mathbf{3}$ in $61 \%$ yield. A similar Swern oxidation by the use of trifluoroacetic anhydride instead of oxalyl chloride increased the yield of $\mathbf{3}$ to $73 \%$. The overall yield of $\mathbf{3}$ from $\mathbf{4}$ was 57\% yield, which is much higher than that from $\mathbf{1}$ (38\% by our hands).<smiles>O=c1oc(Cl)c(Cl)o1</smiles>

1<smiles>O=c1occo1</smiles>

4
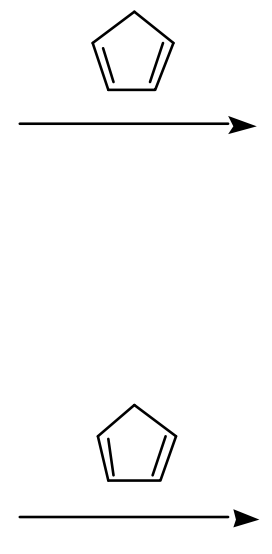

5
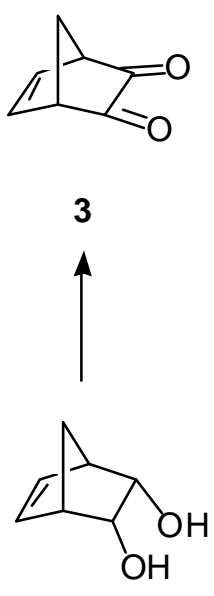

6

Scheme 1.

We next tried to apply the Swern oxidation to prepare pyrazine-fused norbornenediones $\mathbf{1 4}$. 5,6,7,8Tetrahydro-5,8-methanoquinoxaline-6-exo,7-exo-diol (10) was prepared in $90 \%$ yield by the oxidation of pyrazine-fused norbornadiene 7 [6] with osmium tetroxide in the presence of $N$-methylmorpholine $N$-oxide. A similar oxidation of 8 [6] provided 1,2,3,4-tetrahydro-1,4-methanophenazine-2-exo,3-exo-diol (11) in 89\% yield. However, treatment of the dicyanopyrazine-fused norbornadiene 9 [6] with osmium tetroxide resulted in the recovery of 9. The electron-deficient pyrazine ring with cyano substituents would retard the oxidation at the remote olefinic moiety [7].

When the exo-cis diol 10 was treated with dimethyl sulfoxide and trifluoroacetic anhydride, (6,7-dihydro5H-cyclopentapyrazin-5-yl)methanol (12) was obtained in 75\% yield. A similar treatment of $\mathbf{1 1}$ provided (2,3-dihydro-1H-cyclopenta[b]quinolin-1-yl)methanol (13) in 63\% yield. The Swern oxidation of 11 by the use of oxalyl chloride instead of trifluoroacetic anhydride also produced $\mathbf{1 3}$ in $63 \%$ yield. We could observe no evidence for the formations of expected $\alpha$-diketones 14 . When we were monitoring the reaction by TLC, a spot initially formed on the TLC plate was disappeared after the work-up with aqueous sodium hydroxide solution. Unfortunately, our attempts to isolate the intermediate corresponding to this spot were unsuccessful. 


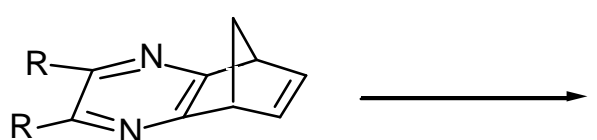

$7 \mathrm{R}=\mathrm{H}$

$8 \mathrm{R}-\mathrm{R}=\mathrm{CH}=\mathrm{CH}-\mathrm{CH}=\mathrm{CH}$

$9 \mathrm{R}=\mathrm{CN}$<smiles></smiles>

$10 \mathrm{R}=\mathrm{H}$

$11 \mathrm{R}-\mathrm{R}=\mathrm{CH}=\mathrm{CH}-\mathrm{CH}=\mathrm{CH}$<smiles>[R]c1nc2c(nc1[R])C(CO)CC2</smiles>

$12 \mathrm{R}=\mathrm{H}$

$13 \mathrm{R}-\mathrm{R}=\mathrm{CH}=\mathrm{CH}-\mathrm{CH}=\mathrm{CH}$<smiles>[R]c1nc2c(nc1[R])C1CC(C(=O)C2=O)C1CCCCCCCCCC</smiles>

14

\section{Scheme 2.}

A plausible mechanism for the present reaction was illustrated in Scheme 3. The initially formed sulfonium ion 15 would undergo the $\mathrm{C}-\mathrm{C}$ bond cleavage by the abstraction of hydroxyl proton with triethylamine, and the intramolecular Cannizzaro reaction under alkaline conditions followed by decarboxylation could give the products 12 and 13.

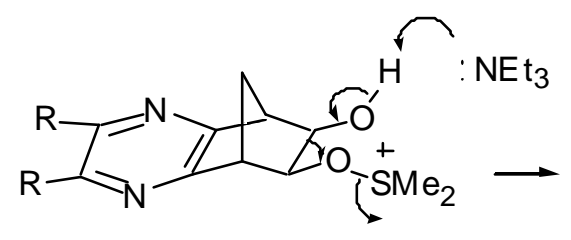

15<smiles>[R]c1nc2c(nc1[R])C(C=O)CC2C</smiles>

16<smiles>[R]c1nc2c(nc1[R])C(C(O)=[Te])CC2CO</smiles><smiles>[3H]C(=O)O[Na]</smiles>

12,13

\section{Scheme 3.}

However, the Cannizzaro reaction is well recognized to proceed for aldehydes with no $\alpha$-hydrogen [8]. Furthermore, the Swern oxidations of vicinal diols 18 [9], 19 [10] and 20 [11] have all been reported to give the corresponding $\alpha$-diketones, as did the oxidation reaction of $\mathbf{6}$. Thus, from our results we did not obtain evidence to discriminate between those reaction pathways and other potential mechanisms for the present reaction might be considered.

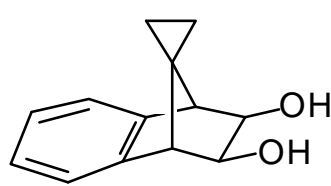

18

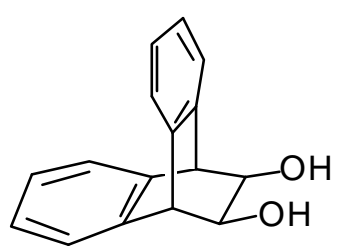

19

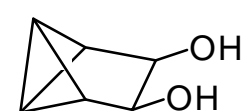

20

Scheme 4. 


\section{Conclusion}

We have presented a facile route for the synthesis of the norbornenedione $\mathbf{3}$ and an unusual ring-opening reaction by Swern oxidation of the pyrazine-fused norbornenediols $\mathbf{1 0}$ and $\mathbf{1 1}$.

\section{Experimental}

\section{General}

All the melting points were determined with a Yanagimoto hot-stage apparatus. IR spectra were obtained with a JEOL Diamond-20 spectrometer. NMR spectra were recorded either with JEOL JNM-LA400 ${ }^{1} \mathrm{H}$ : $400 \mathrm{MHz} ;{ }^{13} \mathrm{C}: 100 \mathrm{MHz}$ ) spectrometer using TMS as internal standard. $J$-Values are given in Hz. Assignments of the ${ }^{1} \mathrm{H}$ and ${ }^{13} \mathrm{C}$ signals are based on DEPT, H-H COSY, and C-H COSY measurements. Mass spectra were measured with a Shimadzu GCMS-QP1000EX spectrometer operating in the electron impact mode $(70 \mathrm{eV})$. High-resolution mass spectra (HR-MS) were taken with a JEOL JMS-SX102A spectrometer operating in the FAB+ method. Elemental analyses were performed with a Perkin-Elmer Model 240 apparatus. Solvents were dried and purified by standard methods. Yields are based on isolated products with sufficient purity.

\section{Bicyclo[2.2.1]hept-5-ene-2,3-dione (3)}

Trifluoroacetic anhydride (35.92 g, $171 \mathrm{mmol}$ ) was added dropwise over $40 \mathrm{~min}$ to a solution of dimethyl sulfoxide $(14.79 \mathrm{~g}, 189 \mathrm{mmol})$ in dichloromethane $(100 \mathrm{~mL})$ cooled with a dry ice-acetone bath. To this solution was added a solution of bicyclo[2.2.1]hept-5-ene-2-endo,3-endo-diol (6) (7.50 g, $60 \mathrm{mmol}$ ) in dichloromethane $(30 \mathrm{~mL})$ over $10 \mathrm{~min}$. The mixture was further stirred at $-78^{\circ} \mathrm{C}$ for $2 \mathrm{~h}$. Triethylamine $(31.98 \mathrm{~g}$, $316 \mathrm{mmol}$ ) was added to the solution. The mixture was stirred for $3 \mathrm{~h}$ and allowed to warm up to room temperature. 2M Hydrochloric acid was added and the product was extracted with dichloromethane. The organic phase was dried with sodium sulfate. After removal of the solvent, the resulting yellow oil was distilled under vacuum to give 3 (5.31 g, 73\%) as a yellow oil which solidified after cooling: bp $129^{\circ} \mathrm{C}$ (10 Torr); mp $40^{\circ} \mathrm{C}$ (lit [3] mp 43 $\left.{ }^{\circ} \mathrm{C}\right) ;{ }^{1} \mathrm{H}$ NMR $\left(\mathrm{CDCl}_{3}\right) \delta=2.49(1 \mathrm{H}, \mathrm{d}, J=11,7-\mathrm{H}), 3.00(1 \mathrm{H}, \mathrm{dt}, J=11$ and 2, 7-H), 3.32 $(2 \mathrm{H}, \mathrm{m}, 1-\mathrm{H}$ and $4-\mathrm{H}), 6.51\left(2 \mathrm{H}\right.$, br s, 5-H and 6-H); ${ }^{13} \mathrm{C} \mathrm{NMR}\left(\mathrm{CDCl}_{3}\right) \delta=43.6(\mathrm{C}-7), 51.4(\mathrm{C}-1$ and $\mathrm{C}-$ 4), 137.7 (C-5 and C-6), 195.6 (C-2 and C-3); IR (KBr) $1765 \mathrm{~cm}^{-1}$; MS m/z 122 (9; $\left.\mathrm{M}^{+}\right), 95$ (16; M $\left.\mathrm{C}_{2} \mathrm{H}_{3}\right), 66\left(100, \mathrm{C}_{5} \mathrm{H}_{6}\right)$.

A similar reaction of $\mathbf{6}(0.65 \mathrm{~g}, 5.8 \mathrm{mmol})$ with dimethyl sulfoxide $(1.19 \mathrm{~g}, 15 \mathrm{mmol})$ and oxalyl chloride $(1.65 \mathrm{~g}, 13 \mathrm{mmol})$, followed by the addition of triethylamine $(2.70 \mathrm{~g}, 27 \mathrm{mmol})$ provided $\mathbf{3}(0.43 \mathrm{~g}, 61 \%)$.

\section{5,6,7,8-Tetrahydro-5,8-methanoquinoxaline-6-exo,-7-exo-diol (10)}

To a solution of osmium tetroxide $(1 \mathrm{mg}, 0.004 \mathrm{mmol})$ and $N$-methylmorpholine $N$-oxide (246 mg, 2.1 $\mathrm{mmol})$ in a mixture of acetone $(5 \mathrm{~mL})$ and water $(10 \mathrm{~mL})$ was added the norbornadiene-fused pyrazine 7 $(100 \mathrm{mg}, 0.7 \mathrm{mmol})$ and the mixture was stirred at room temperature for $68 \mathrm{~h}$. Sodium sulfite $(3 \mathrm{mg}, 0.03$ $\mathrm{mmol})$ and florisil $(0.5 \mathrm{~g})$ was added to the reaction mixture and insoluble materials were filtered through celite. 
Aqueous sodium hydroxide solution was added to the filtrate and products were extracted with dichloromethane $(6 \times 20 \mathrm{~mL})$. The combined organic phases were dried over sodium sulfate. After removal of the solvent, the residue was purified by column chromatography (silica gel, ethyl acetate), and the resulting solid was recrystallized from chloroform to give $\mathbf{1 0}(112 \mathrm{mg}, 90 \%)$ as a white solid: $\mathrm{mp} 186-187^{\circ} \mathrm{C} ;{ }^{1} \mathrm{H}$ NMR $\left(\mathrm{CDCl}_{3}\right) \delta=2.17\left(1 \mathrm{H}, \mathrm{dm}, J=14,9-\mathrm{H}_{\mathrm{s}}\right), 3.00\left(1 \mathrm{H}, \mathrm{dt}, J=14\right.$ and 2, 9- $\left.\mathrm{H}_{\mathrm{a}}\right), 3.45(2 \mathrm{H}, \mathrm{t}, J=2,5-\mathrm{H}$ and $8-\mathrm{H})$, 3.99 (2H, br s, 6-H and 7-H), 4.15 (2H, s, OH, disappeared by $\mathrm{D}_{2} \mathrm{O}$ addition), 8.16 (2H, s, 2-H and 3-H); ${ }^{13} \mathrm{C} \mathrm{NMR}\left(\mathrm{CDCl}_{3}\right) \delta=41.2(\mathrm{C}-5$ and C-8), $51.4(\mathrm{C}-9), 69.7$ (C-2 and C-3), 141.7 (C-6 and C-7), 161.1 (C-4a and C-8a); IR (KBr) 3490, 3097, 1365, $1160 \mathrm{~cm}^{-1}$; MS m/z 178 (33; M+), 149 (31; M - CHO), 119 (100, M - 2CHO - H). Anal. Found: C, 60.52; H, 5.96; N, 15.67\%. Calcd for $\mathrm{C}_{9} \mathrm{H}_{10} \mathrm{~N}_{2} \mathrm{O}_{2}: \mathrm{C}, 60.66 ; \mathrm{H}$, $5.66 ; \mathrm{N}, 15.72 \%$.

\section{1,2,3,4-Tetrahydro-1,4-methanophenazine-2-exo,3-exo-diol (11)}

By a similar procedure as described for 10, the norbornadiene-fused quinoxaline $\mathbf{8}$ (349 $\mathrm{mg}, 1.8 \mathrm{mmol}$ ) provided 11 (366 mg, 89\%) as a white solid after recrystallization from chloroform: $\mathrm{mp} 183-184^{\circ} \mathrm{C} ;{ }^{1} \mathrm{H} \mathrm{NMR}$ $\left(\mathrm{CDCl}_{3}\right) \delta=2.23\left(1 \mathrm{H}, \mathrm{dm}, J=11,11-\mathrm{H}_{\mathrm{s}}\right), 2.65\left(1 \mathrm{H}, \mathrm{d}, J=11,11-\mathrm{H}_{\mathrm{a}}\right), 3.58(2 \mathrm{H}, \mathrm{s}, 1-\mathrm{H}$ and $4-\mathrm{H}), 3.77(2 \mathrm{H}$, $\mathrm{s}, \mathrm{OH}$, disappeared by $\mathrm{D}_{2} \mathrm{O}$ addition), $4.14(2 \mathrm{H}, \mathrm{s}, 2-\mathrm{H}$ and $3-\mathrm{H}), 7.70(2 \mathrm{H}, \mathrm{m}, 7-\mathrm{H}$ and $8-\mathrm{H}), 8.00(2 \mathrm{H}, \mathrm{m}$, 6-H and 9-H); ${ }^{13} \mathrm{C}$ NMR $\left(\mathrm{CDCl}_{3}\right) \delta=39.0(\mathrm{C}-1$ and $\mathrm{C}-4), 51.3(\mathrm{C}-11), 76.3$ (C-2 and C-3), 128.7 (C-7 and C-8), 129.4 (C-6 and C-9), 141.4 (C-5a and C-9a), 160.8 (C-4a and C-10a); IR (KBr) 3430, 3074, $1076 \mathrm{~cm}^{-1}$; MS m/z 228 (59; $\mathrm{M}^{+}$), 199 (31; M - CHO), 169 (100, M - 2CHO - H). Anal. Found: C, 68.41; $\mathrm{H}, 5.30 ; \mathrm{N}, 12.27 \%$. Calcd for $\mathrm{C}_{13} \mathrm{H}_{12} \mathrm{~N}_{2} \mathrm{O}_{2}$ : C, 68.68, H, 5.21; N, $12.01 \%$.

\section{The Swern Oxidation of $\mathbf{1 0}$}

To a cooled $\left(-78^{\circ} \mathrm{C}\right)$ solution of dimethyl sulfoxide $(125 \mathrm{mg}, 1.6 \mathrm{mmol})$ in dichloromethane $(10 \mathrm{~mL})$ was added trifluoroacetic anhydride ( $315 \mathrm{mg}, 1.5 \mathrm{mmol})$ over $5 \mathrm{~min}$. A solution of $\mathbf{1 0}(89 \mathrm{mg}, 0.5 \mathrm{mmol})$ in a 1:1 mixture $(5 \mathrm{~mL})$ of dichloromethane and dimethyl sulfoxide was added over $10 \mathrm{~min}$ and the mixture was stirred at $-78^{\circ} \mathrm{C}$ for $3 \mathrm{~h}$. Triethylamine ( $268 \mathrm{mg}, 2.7 \mathrm{mmol}$ ) was introduced to the solution. The mixture was stirred at $-78^{\circ} \mathrm{C}$ for $1.5 \mathrm{~h}$ and allowed to warm up to room temperature. Aqueous sodium hydroxide solution was added and the product was extracted with dichloromethane $(6 \times 20 \mathrm{~mL})$. The combined organic phase was washed with water and dried over sodium sulfate. After removal of the solvent, the residue was separated by column chromatography (silica gel, ethyl acetate) to give (6,7-dihydro-5H-cyclopentapyrazin-5-yl)methanol (12) $(56 \mathrm{mg}, 75 \%)$ as a colorless liquid: ${ }^{1} \mathrm{H}$ NMR $\left(\mathrm{CDCl}_{3}\right) \delta=1.98(1 \mathrm{H}$, ddd, $J=19,11$ and 9, 6-H), 2.37 (1H, ddd, $J=19,8$ and 6, 6-H), $3.07(2 \mathrm{H}, \mathrm{dd}, J=9$ and 6, 7-H), $3.43(1 \mathrm{H}, \mathrm{m}, 5-\mathrm{H}), 3.80-4.01(3 \mathrm{H}, \mathrm{m}$, $\mathrm{CH}_{2} \mathrm{OH}$ and $\left.\mathrm{OH}\right), 8.24(1 \mathrm{H}$, br s, $2-\mathrm{H}$ or $3-\mathrm{H}), 8.30(1 \mathrm{H}$, br s, $3-\mathrm{H}$ or $2-\mathrm{H}) ;{ }^{13} \mathrm{C} \mathrm{NMR}\left(\mathrm{CDCl}_{3}\right) \delta=24.2$ (C-6), 30.8 (C-7), 45.1 (C-5), $64.9\left(\mathrm{CH}_{2} \mathrm{OH}\right), 141.6$ (C-2 or C-3), 142.7 (C-3 or C-2), 159.9, 160.2; IR (KBr) 3347, 2946, 1388, $1160 \mathrm{~cm}^{-1}$; MS m/z 150 (2; M ), 119 (100, M - $\left.\mathrm{CH}_{2} \mathrm{OH}\right)$. HR-MS (FAB+) found: $151.0899(\mathrm{M}+1)$. Calcd for $\mathrm{C}_{8} \mathrm{H}_{10} \mathrm{~N}_{2} \mathrm{O}: 151.0872(\mathrm{M}+1)$.

\section{The Swern Oxidation of $\mathbf{1 1}$}

By a similar procedure as described for the oxidation of 10, the norbornadiene-fused quinoxaline 11 (114 $\mathrm{mg}, 0.5 \mathrm{mmol}$ ) provided (2,3-dihydro- $1 H$-cyclopenta[b]quinolin-1-yl)methanol (13) $(58 \mathrm{mg}, 63 \%)$ as a white 
solid after recrystallization from hexane: $\mathrm{mp} 83-84^{\circ} \mathrm{C} ;{ }^{1} \mathrm{H} \mathrm{NMR}\left(\mathrm{CDCl}_{3}\right) \delta=1.97(1 \mathrm{H}$, ddd, $J=18,13$, and 9 , 2-H), $2.47(1 \mathrm{H}$, ddd, $J=18,8$, and 5, 2-H), $3.02(1 \mathrm{H}, \mathrm{s}, \mathrm{OH}), 3.22(2 \mathrm{H}, \mathrm{dd}, J=9$ and 5, 3-H), $3.58(1 \mathrm{H}, \mathrm{m}$, $1-\mathrm{H}), 3.98\left(1 \mathrm{H}, \mathrm{dd}, J=11\right.$ and $\left.8, \mathrm{CH}_{2} \mathrm{OH}\right), 4.09\left(1 \mathrm{H}, \mathrm{dd}, \mathrm{J}=11\right.$ and $\left.5, \mathrm{CH}_{2} \mathrm{OH}\right), 7.62(2 \mathrm{H}, \mathrm{m}), 8.02(2 \mathrm{H}$, $\mathrm{m}) ;{ }^{13} \mathrm{C} \mathrm{NMR}\left(\mathrm{CDCl}_{3}\right) \delta=24.3(\mathrm{C}-2), 31.3(\mathrm{C}-3), 45.0(\mathrm{C}-1), 65.1\left(\mathrm{CH}_{2} \mathrm{OH}\right), 128.7,128.8,128.9,129.1$, 141.0, 141.9, 160.6, 161.8; IR (KBr) 3241, 2964, $1342 \mathrm{~cm}^{-1}$; MS m/z $200\left(5 ; \mathrm{M}^{+}\right), 182\left(16, \mathrm{M} \mathrm{M}-\mathrm{H}_{2} \mathrm{O}\right.$ ), 169 (100, M - $\left.\mathrm{CH}_{2} \mathrm{OH}\right)$. HR-MS (FAB+) found: $201.1055(\mathrm{M}+1)$. Calcd for $\mathrm{C}_{12} \mathrm{H}_{12} \mathrm{~N}_{2} \mathrm{O}: 201.1028(\mathrm{M}$ $+1)$.

A similar Swern oxidation of 11 (68 mg, $0.3 \mathrm{mmol})$ by the use of oxalyl chloride (114 $\mathrm{mg}, 0.9 \mathrm{mmol})$ instead of trifluoroacetic anhydride also afforded 13 (38 $\mathrm{mg}, 63 \%)$.

\section{References and Notes}

1. Kamieth, M.; Burkert, U.; Corbin, P. S.; Dell, S. J.; Zimmerman, S. C.; Klämer, F.-G. Eur. J. Org. Chem. 1999, 2741-2749 (and references cited therein).

2. Scharf, H.-D.; Küsters, W. Chem. Ber. 1972, 105, 564-574.

3. Scharf, H.-D.; Pinske, W.; Feilen, M.-H.; Droste, W. Chem.. Ber. 1972, 105, 554-563.

4. Newman, M. S.; Addor, R. W. J. Am. Chem. Soc. 1953, 75, 1263-1264.

5. Newman, M. S.; Addor, R. W. J. Am. Chem. Soc. 1955, 77, 3789-3793.

6. Kobayashi, T.; Miki, K. Bull. Chem. Soc. Jpn. 1998, 71, 1443-1449.

7. Kobayashi, T.; Miki, K.; Nikaeen, B.; Baba, H. Tetrahedron, 1999, 55, 13179-13192.

8. March, J. Advanced Organic Chemistry, 3 rd ed.; John Wiley \& Sons: New York, 1985; p. 1117.

9. Russell, R. A.; Harrison, P. A.; Warrener, R. N. Aust. J. Chem. 1984, 37, 1035-1041.

10. Wright, M. W.; Welker, M. E. J. Org. Chem. 1996, 61, 133-141.

11. Christl, M.; Kraft, A. Angew. Chem., Int. Ed. Engl. 1988, 27, 1369-1370.

Samples Availability: Available from the authors and from MDPI.

(C) 2000 by MDPI (http://www.mdpi.org). 